OPEN ACCESS

Edited by:

Edmundo Acevedo,

Universidad de Chile, Chile

Reviewed by:

Claudio Pastenes,

Universidad de Chile, Chile

Ricardo A. Pertuzé,

Universidad de Chile, Chile

*Correspondence:

Javed lqbal,

Department of Plant Breeding and Genetics, University of Agriculture,

Faisalabad, Faisalabad,

Punjab 38040, Pakistan

raijaved1567@yahoo.com

Specialty section:

This article was submitted to Crop Science and Horticulture,

a section of the journal

Frontiers in Plant Science

Received: 02 June 2015

Accepted: 12 August 2015

Published: 02 September 2015

Citation:

labal J, Ahsan M, Saleem M and Ali A (2015) Appraisal of gene action for indeterminate growth in mungbean [Nigna radiata (L.) Wilczek].

Front. Plant Sci. 6:665. doi: 10.3389/fp/s.2015.00665

\section{Appraisal of gene action for indeterminate growth in mungbean [Vigna radiata (L.) Wilczek]}

\author{
Javed lqbal ${ }^{1 *}$, Muhammad Ahsan ${ }^{1}$, Muhammad Saleem ${ }^{1}$ and Asghar Ali ${ }^{2}$ \\ ${ }^{1}$ Department of Plant Breeding and Genetics, University of Agriculture, Faisalabad, Pakistan, ${ }^{2}$ Department of Agronomy, \\ University of Agriculture, Faisalabad, Pakistan
}

In order to investigate the inheritance pattern of indeterminate growth in Vigna radiata, various related traits were studied. The techniques used for the purpose were generation mean and variance analyses. Narrow sense heritability estimates were also computed. Four out of fifty greengram accessions were selected during preliminary screen trial based on $\mathrm{DDd}_{2}$ and $\mathrm{DDh}_{2}$ values. Two cross combinations were made by utilizing four parents. Generation variance analysis demonstrated the engagement of additive and environmental components, with the pre-pondrance of additive gene action. Narrow sense heritability estimates (>67\%) also supported the same. In generation mean analysis both cross combinations manifested non-allelic epistatic digenic interactions for the investigated traits except for plant height at first flower initiation and for seed yield per plant in one cross combination, where only additive and dominance components were important. For pyramiding the additive genes favoring determinate plant growth, higher harvest index and simultaneously purging the genes promoting twining growth habit escorted with low seed yield, any modified breeding scheme which could serve the said purpose may be opted.

Keywords: degree of indetermination, plant height, yield, harvest index, mungbean

\section{Introduction}

In higher order plant species growth of the flowering stem may be either indeterminate or determinate (Weberling, 1989). The apex grows for indefinite period with the production of flowers in continuous succession in case of indeterminate plant growth (Lampang et al., 1988). While in case of determinate growth, the vegetative stage/phase terminates prior to blooming. One criterion for greengram categorization could be the plant growth habit. In legumes crops indeterminate/twinning growth habit is a natural phenomenon (Tickoo et al., 1996). The same is a serious obstacle while achieving a satisfactory crop yield during first picking. In this regard, a portion of photosynthates actually consumed while supporting the vegetative plant growth. Increase in plant height, accumulation of dry matter, including leaf area index (LAI) may be called as vegetative growth. Maximum vegetative growth prior to flowering is desirable while minimum increase in plant height after that is advantageous so as to minimize the competition among plants (Shanmugasundaram et al., 1977) with effective utilization of photosynthates for fruiting purpose. During pods development phase effective utilization of assimilates is necessary. For accomplishing the same large general combing ability effect for plant height after first flower to $90 \%$ pods maturity is mandatory (Tickoo et al., 1996). But Initial studies have revealed that determinate genotypes of 
some legumes gave low yield in comparison to indeterminate types (Podleœny, 2001). Apparently indeterminate growth is a desirable plant feature but the same unnecessarily prolongs the crop ripening period. From the farmer's point of view, indeterminate growth is not necessary, because extra pickings become mandatory for attaining a satisfactory crop yield. Ultimately the cost of production escalates. Indeterminate plant growth is also an obstacle toward mechanical harvesting of the crop. In this scenario, development of mungbean lines with no or minimum twining growth at the onset of blooming phase with maximum seed yield and higher harvest index will be the ultimate choice of the farmer. For accomplishing the said task, an understanding of the genetic mechanisms controlling the inheritance of plant height at various reproductive stages is mandatory. This may aid in devising a work oriented breeding strategy for curtailing the indeterminate growth in mungbean. Keeping in view the importance of determinate type of plant growth and attributing traits, present study was designed to assess the extent of gene/genes governing the inheritance of said parameters.

\section{Materials and Methods}

\section{Selection of Parents for Genetic Studies}

The research studies pertaining to the mode of inheritance of plant height, degree of indeterminations of plant height and other growth related traits were conducted at the experimental area of the Department of Plant Breeding and Genetics, University of Agriculture, Faisalabad, Pakistan during
2009-2010. Fifty diverse mungbean lines including those which were characterized for their determinate/indeterminate growth habit were obtained from various national research institutes (Table 1). For screening the appropriate parents, a triplicate randomized complete block design was exercised. Row length was maintained at $4 \mathrm{~m}$, while $30 \mathrm{~cm}$ distance was kept between rows. A recommended plant spacing $(10 \mathrm{~cm})$ was followed. For digging the holes at the marked areas of the soil a hand-held dibbler was used. Manually added 2-3 seeds per hole. One week after germination thinning was performed. One vigorous seedling was kept per hole. Recommended agronomic and plant protection measures were adopted. Five random and guarded plants from each genotype within a replication were selected for recording the following data:

\section{At Screening:}

Days to first pod maturity $=$ D2

Days to $90 \%$ pods maturity $=\mathbf{D} 3$

Plant height $(\mathrm{cm})$ at first flower initiation $=\mathbf{H 1}$

Plant height $(\mathrm{cm})$ at $90 \%$ pods maturity $=\mathbf{H 3}$

$\mathrm{DDd}_{2}$ was calculated according to the formula outlined by Khattak et al. (2004)

Degree of indetermination (DD) of pod maturity (DDd) from first pod maturity to $90 \%$ pods maturity $=\mathbf{D D d}_{2}=\mathrm{D} 3-\mathrm{D} 2 / \mathrm{D} 3 \times$ 100

Degrees of indeterminations of plant height $\left(\mathrm{DDh}_{1}, \mathrm{DDh}_{2}\right.$, and $\mathrm{DDh}_{3}$ ) were computed by following Khattak et al. (2002b).

Degree of indetermination (DD) of plant height (DDh) from first flower to $90 \%$ pods maturity $=\mathbf{D D h}_{2}=\mathrm{H} 3-\mathrm{H} 1 / \mathrm{H} 3 \times 100$.

\begin{tabular}{|c|c|c|c|c|c|c|c|c|}
\hline G2 & 07002 & PRI,AARI, Fsd. & G19 & NM 20-21 & NIAB, Fsd. & G36 & AUM-38 & UAF \\
\hline G3 & 07003 & PRI,AARI, Fsd. & G20 & NM 98 & NIAB, Fsd. & G37 & AUM-27 & UAF \\
\hline G4 & 07005 & PRI,AARI, Fsd. & G21 & NM 19-19 & NIAB, Fsd. & G38 & M-2004 & UAF \\
\hline G6 & AZRI-2006 & PRI,AARI, Fsd. & G23 & Var-6601* & NIAB, Fsd. & G40 & VC-1482 & NIAB/AVRDC \\
\hline G7 & 97002 & PRI,AARI, Fsd. & G24 & NM-28 & NIAB, Fsd. & G41 & VC-1560* & NIAB/AVRDC \\
\hline G8 & 97004 & PRI,AARI, Fsd. & G25 & NM-51 & NIAB, Fsd. & G42 & VC-1628 & NIAB/AVRDC \\
\hline G9 & 97006 & PRI,AARI, Fsd. & G26 & NM 121-25 & NIAB, Fsd. & G43 & VC-2754 & NIAB/AVRDC \\
\hline G10 & 97012 & PRI,AARI, Fsd. & G27 & AUM-6375 & UAF & G44 & VC-2771 & NIAB/AVRDC \\
\hline G15 & 98009 & PRI,AARI, Fsd. & G32 & AUM-31 & UAF & G49 & VC-3960 & NIAB/AVRDC \\
\hline G16 & NM-2006 & NIAB, Fsd. & G33 & AUM-24 & UAF & G50 & VC-6369 & NIAB/AVRDC \\
\hline G17 & NM 13-1 & NIAB, Fsd. & G34 & AUM-28 & UAF & & & \\
\hline
\end{tabular}

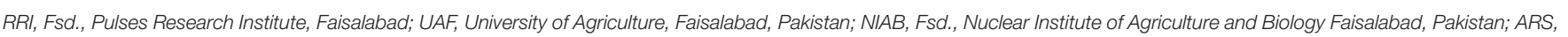

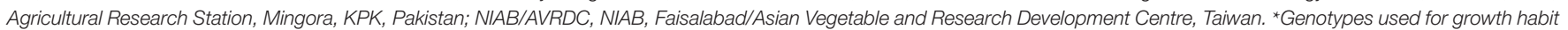
studies (Khattak et al., 2002b, 2004). 


\section{At Final Evaluation:}

Plant height $(\mathrm{cm})$ at first flower initiation $=\mathbf{H 1}$

Plant height $(\mathrm{cm})$ at first pod maturity $=\mathbf{H 2}$

Plant height $(\mathrm{cm})$ at $90 \%$ pod maturity $=\mathbf{H 3}$

Degree of indetermination of plant height from first flower to first pod maturity $=\mathbf{D D h}_{\mathbf{1}}=\mathrm{H} 2-\mathrm{H} 1 / \mathrm{H} 2 \times 100$

Degree of indetermination of plant height from first flower to $90 \%$ pods maturity $=\mathbf{D D h}_{2}=\mathrm{H} 3-\mathrm{H} 1 / \mathrm{H} 3 \times 100$

Degree of indetermination of plant height from first pod maturity to $90 \%$ pods maturity $=\mathbf{D D h}_{3}=\mathrm{H} 3-\mathrm{H} 2 / \mathrm{H} 3 \times 100$

Nodes per plant (no.)

Biological yield per plant (g)

Seed yield per plant $(\mathrm{g})$

Harvest Index $(\%)=($ Seed yield per plant/Biological yield per plant $) \times 100$ (Reddy, 2004).

Four genotypes with lowest and the highest $\mathrm{DDd}_{2}$ and $\mathrm{DDh}_{2}$ values were selected. By utilizing the selected four parents two cross combinations were made. Six basic populations (P1, P2, F1, F2, BC1, and BC2) of two crosses were developed (autumn-2009spring-2010). During final evaluation (autumn 2010), a Complete Randomized Block Design with three replications was exercised. The parents, F1 and back crosses were sown in two rows each, F2 in 20 rows. Twenty random plants were selected from each parent and F1 generation, while plants earmarked from each back cross (BC1 and BC2) and $\mathrm{F} 2$ populations were 50 and 100, respectively within a replication. Analysis of variance (ANOVA) and its partitioning was performed according to Steel et al. (1997) by using "Statistix v 8.1" computer software.

\section{Generation Mean and Variance Analyses}

Generation mean analysis was carried out as per Mather and Jinks (1982) by utilizing a computer program supplied by Dr. JW Snape, Cambridge Laboratory, Norwich, for the study of gene action of characters. Mather and Jinks (1982) also outlined the weighted least squares analysis of variance. The same was followed for the experiment comprised of six basic populations. For the purpose a computer programme supplied by Dr. H. S. Pooni, University of Birmingham, UK was utilized. Means and variances of six populations used in the analysis were calculated from individual plants pooled over replications. Characters of the six populations were compared to test the validity of additivedominance model using Chi-square $(\chi 2)$ test. Initially simplest model of weighted least square analysis was carried out on generation mean of traits using parameter " $m$ " only. Based on significance of Chi-square value further models $\mathrm{md}$, mdh etc. were adopted. Best selected model taken was the one, with significant values for all the parameters along with nonsignificant chi-square. Sum of squares for those comparisons were calculated using formula outlined by Little and Hills (1978).

$$
\mathrm{SS}=\left(\Sigma \mathrm{c}_{\mathrm{i}} \mathrm{Yi}\right) 2 / \mathrm{r} \Sigma \mathrm{c}_{\mathrm{i}} 2
$$

Where,

SS $=$ sum of squres of comparison

$\Sigma=$ summation

$\mathrm{C}_{\mathrm{i}}=$ comparison coefficients

$\mathrm{Y}_{\mathrm{i}}=$ generation totals

$\mathrm{r}=$ replications
Narrow sense heritability ( $h^{2}$ n.s.) for $F 2$ and infinite $\left(F_{\propto}\right)$ generations were also computed from variance components (D and E) of generation variance analysis

$$
\mathrm{h}_{(\mathrm{F} 2)}^{2}=0.5 \mathrm{D} /(0.5 \mathrm{D}+\mathrm{E})
$$

(when the simple DE model fitted the data)

$$
\mathrm{h}_{(\mathrm{F} \propto)}^{2}=\mathrm{D} /(\mathrm{D}+\mathrm{E})
$$

where,

$\mathrm{D}=$ additive genetic component

$\mathrm{E}=$ environment components

\section{Results}

\section{Screening of Parents and Preliminary Analysis of Variance}

Fifty mungbean (Table 1) genotypes were studied for range of variability regarding degree of indetermination of pod maturity from first pod maturity to $90 \%$ pods maturity $\left(\mathrm{DDd}_{2}\right)$ and degree of indetermination of plant height from first flower to $90 \%$ pods maturity $\left(\mathrm{DDh}_{2}\right)$. The objective was to earmark the parents for hybridization and further studies. Creation of genetic variation and its manipulation plays a decisive role while working out a result oriented breeding strategy (Khattak et al., 2004; Ali et al., 2008). Choice of the parent(s) and selection of trait(s) actually determine the extent of gene action (Kwaye et al., 2008). After collecting data for six various traits at different maturity stages an ordinary analysis of variance (Table 2) was performed. The results signified the existence of variability for the investigated plant characters. Maximum diversity was observed between the parents for the studied traits. Non-significant differences among all the interacting populations were witnessed (Table 3 ) for the traits, plant height at first flower initiation in both crosses, while for plant height at $90 \%$ pods maturity, $\mathrm{DDh}_{1}, \mathrm{DDh}_{2}, \mathrm{DDh}_{3}$ and seed yield per plant in one cross combination. Both back cross generations (BC1 and $\mathrm{BC} 2$ ) behaved non-significantly for plant height at first flower initiation, $\mathrm{DDh}_{3}$, nodes per plant and seed yield per plant in one cross combination. Maximum genetic similarity was observed between the back cross generations (BC1 and BC2) and the F2 population for the traits, plant height at first flower and $90 \%$ pods maturity, all degree of indeterminations of plant height, nodes per plant and seed yield.

A scatter plot (Figure 1) was constructed between two variables. In which the variable $\mathrm{DDd}_{2}$ was taken at $\mathrm{X}$-axis, while $\mathrm{DDh}_{2}$ at Y-axis (Rehman et al., 2009, 2010). The diagram provided the information that two varieties (AZRI-2006 and $\mathrm{NM}-2006)$ fall in the zone where the value of $\mathrm{DDd}_{2}$ and $\mathrm{DDh}_{2}$ was at its minimum $(<38)$. Accordingly genotype 97006 and AUM-9 had the highest $\operatorname{DDd}_{2}(>47)$ and $\mathrm{DDh}_{2}(>56)$ values. Most of the genotypes for the trait $\mathrm{DDd}_{2}$ ranged from 38 to 48 and that of $\mathrm{DDh}_{2}$ from 40 to 50 . Thirty eight genotypes were found in that particular patch. A line drawn from the point 38.5 representing generation mean for $\mathrm{DDh}_{2}$ on Y-axis, which divided the graph into two portions, each half contains exactly 25 genotypes. Resultantly two varieties (AZRI-2006 and 
NM-2006) with lowest and the other two genotypes (97006 and AUM-9) with highest $\mathrm{DDd}_{2}$ and $\mathrm{DDh}_{2}$ values were selected for hybridization and further progenies development. Accordingly after raising the six populations of two crosses, genetic studies were performed.

\section{Gene Action for Various Traits}

A generation mean analysis was used for computing of gene action. The said method is effective for the estimation of additive,

TABLE 2 | Mean squares of 50 mungbean genotypes for six traits during spring season.

\begin{tabular}{lcc}
\hline Trait & D.F. & Mean squares \\
\hline Days to first pod maturity & 49 & $12.72^{\star \star}$ \\
Days to 90\% pods maturity & 49 & $109.7^{\star \star}$ \\
$\mathrm{DDd}_{2}$ & 49 & $53.18^{\star \star}$ \\
Plant height at first flower initiation & 49 & $17.05^{\star \star}$ \\
Plant height at 90\% pods maturity & 49 & $84.77^{\star \star}$ \\
$\mathrm{DDh}_{2}$ & 49 & $78.70^{\star \star}$ \\
\hline
\end{tabular}

${ }^{* *} P<0.01$ dominance and epistatic genetic components, also important for measuring the environmental $(\mathrm{E})$ and $\mathrm{G} \times \mathrm{E}$ interaction (Mather and Jinks, 1982). In addition to other components, additive and dominance genetic effects were the integral part of inheritance for the studied traits, except for plant height at first pod maturity, biological yield per plant and harvest index in NM-2006 $\times$ AUM-9 cross, in which dominance component was missing. For plant height at first flower initiation in both crosses and for seed yield per plant in one cross combination only additive and dominance genetic components were important (Table 4) but with a negative dominance. In contrary the said components was also positive for $\mathrm{DDh}_{3}$ in case of NM-2006/AUM-9. For the trait, plant height at first pod maturity in the said cross only additive and [i] type epistasis was observed. Additive $\times$ additive digenic epistatic interaction was present for seed yield per plant in AZRI-2006/97006 cross. Positive [i] and [j] epistatic digenic interaction was witnessed for $\mathrm{DDh}_{2}$. The said interactions were also present for the inheritance of plant height at first and $90 \%$ pod maturity, biological yield per plant in one studied cross, with negative value of at least one epistatic component. Similarly [j] and [1] epistatic digenic interactions were observed for $\mathrm{DDh}_{1}$ in both the studied greengram crosses and for $\mathrm{DDh}_{2}, \mathrm{DDh}_{3}$ and

TABLE 3 | Mean squares with partitioned generation variances for various traits in two crosses of mungbean.

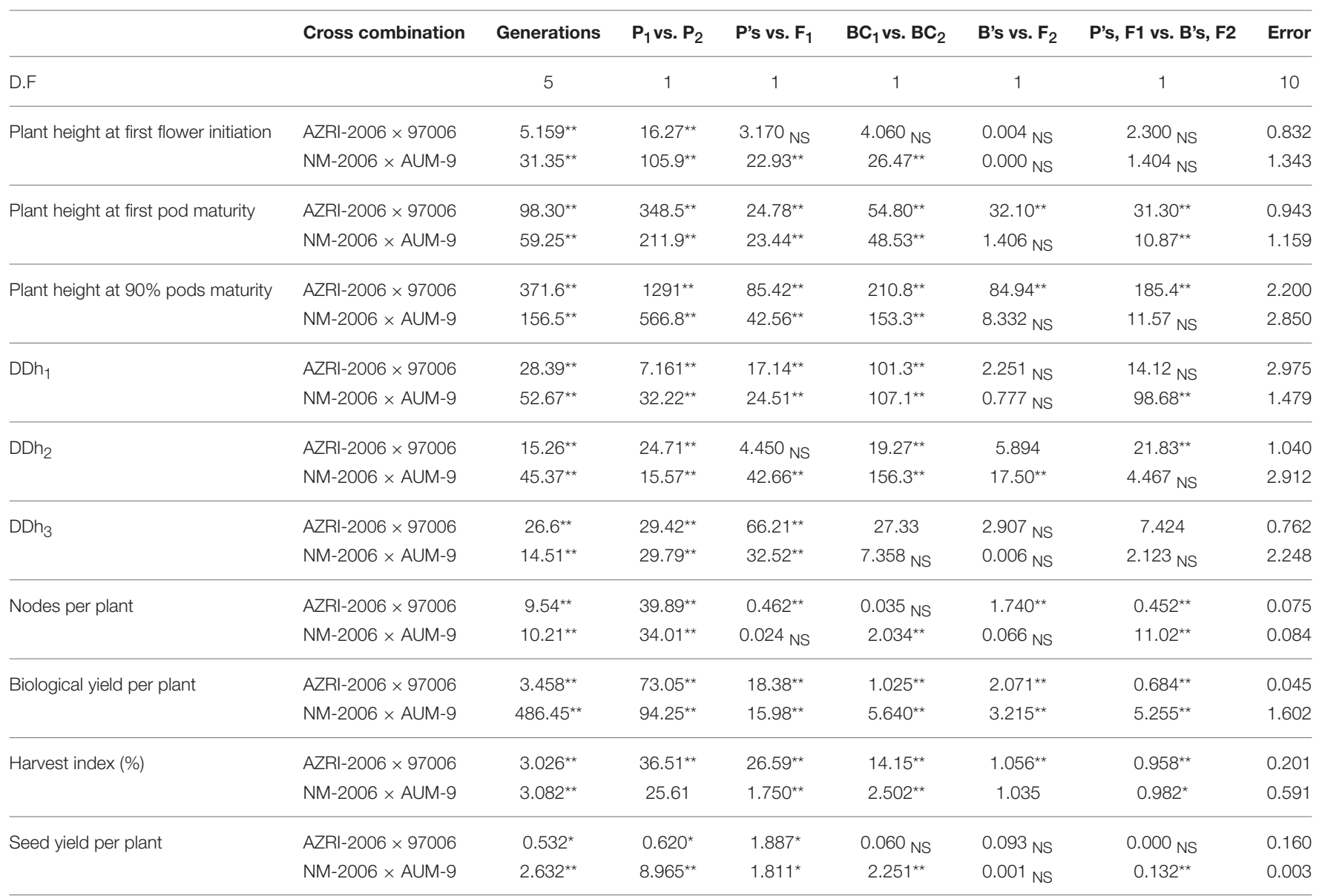

NS, Non-significant, ${ }^{*} P<0.05$ and ${ }^{* *} P<0.01$.

$P_{1}$, Fist parent, $P_{2}$, Second parent, $F_{1}$, First filial generation, $B C_{1}$, Progeny of $F_{1}$ generation after crossing with first parent involved in a cross, $B C_{2}$, Progeny of $F_{1}$ generation after crossing with first parent involved in a cross, $F_{2}$, Second Filial generation. 


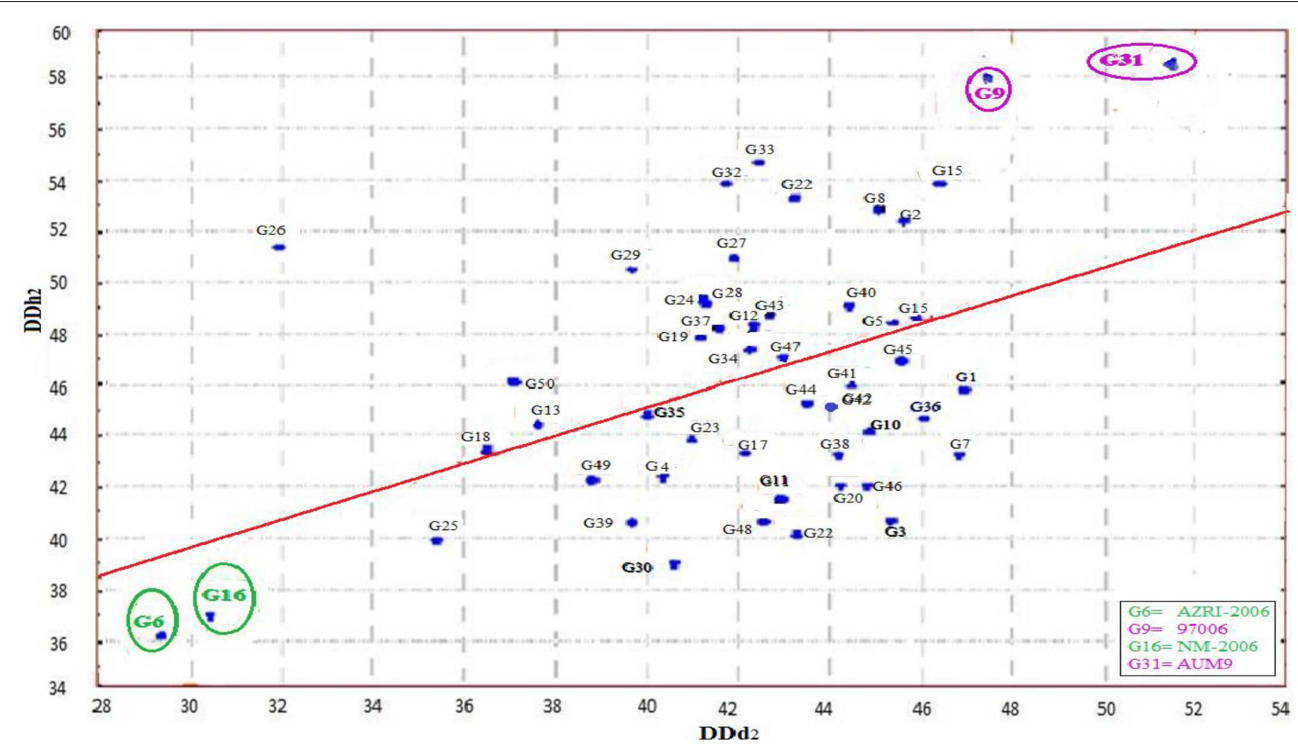

FIGURE 1 | Scatter plot of $\mathrm{DDd}_{2}$ against $\mathrm{DDh}_{2}$.

for biological yield per plant in a single cross. Only negative [i] interaction was noticed for plant height at $90 \%$ pods maturity, [j] for harvest index and [1] type interaction for nodes per plant.

\section{Genetic Component of Variance and Narrow Sense Heritability Estimates}

Generation variance analysis can partition the total variation into different components i.e., additive (D), dominance $(\mathrm{H})$, environmental (E) and interaction (F). Non-segregating (e.g., pure lines, inbred lines, F1 etc.) and segregating (e.g., backcrosses and F2) populations were utilized for the estimation of genetic and environmental component of variance in the present study (Table 5). A non-significant $\chi^{2}$ value was observed with two parameters $[\mathrm{DE}]$ model only. Additive component of variance (D) was much higher than the corresponding environmental (E) variance in all the studied traits, except for seed yield per plant. The values of additive and environmental components ranged from 3.262-206.1 and 0.237-31.90, respectively for AZRI-2006 × 97006 cross. The values for the same parameters ranged from 0.132-127.6 and 0.089-14.03, respectively in NM-2006/AUM-9.

Narrow sense heritability F2 generation $\left(\mathrm{h}_{\mathrm{F} 2}^{2}\right)$ was minimum for the trait; biological yield per plant and maximum for seed yield per plant with respective values 69.7 and 92.6 (Table 5), for AZRI-2006 $\times 97006$ cross. The said heritability estimate was minimum for biological yield per plant (68.2) and maximum for seed yield per plant (86.4) in NM-2006 $\times$ AUM-9 cross. Infinite generation narrow sense heritability $\left(\mathrm{h}_{\mathbf{F} \propto}^{2}\right)$ was minimum for biological yield per plant and maximum for seed yield per plant, surpassing plant height at $90 \%$ pods maturity with respective values 69.7, 96.0, and 94.9, for AZRI-2006 × 97006 cross. Similarly for NM-2006 $\times$ AUM-9 cross combination minimum narrow sense heritability for infinite generation was witnessed for biological yield per plant (68.2) and maximum for seed yield per plant (92.7).

\section{Discussion}

Determinate plant growth in grain legumes could facilitate effective assimilates partitioning and dwarfism could bring reduction in lodging. Modification in leaf size, structure and LAI could improve the light interception efficiency and ultimately the harvest index of the crop. Thereby modified crop architecture could play a pivotal role while improving the adoptability of the grain legumes to wider environmental conditions and to increase the seed yield and its stability (Huyghe, 1998). Both crop and plant architecture fluctuates with a change in plant growth and dry matter accumulation. With an efficient breeding strategy crop architect could be modified. Observations were made regarding the influential impact of plant stem growth on various agronomical characters. For instance determinate plants remained dwarf, resist lodging and have lower lowestpod heights and maximum main stem branches in comparison to indeterminate genotypes at similar maturity (Ouattara and Weaver, 1994; Robinson and Wilcox, 1998; Kilgore-Norquest and Sneller, 2000). The transition from vegetative to reproductive phase at the shoot apical meristem is controlled by the interaction of positive and negative regulators and triggered through genes (Benlloch et al., 2007). The same control the floral primordia development at the summit of an inflorescence apex. Therefore, an understanding about the nature and extent of such gene/genes is pre-requisite for launching an effective breeding plan. But for the manipulation of this aspect, availability of a diversified genetic stock with both the extremes of characters is necessary. Subsequently intermating the genetically diverse parents could enhance the genetic variance by supporting more than one optimum in a plant population (Manifesto et al., 2001). The scatter plot revealed that AZRI-2006 and NM-2006 were the most synchronous maturing $\left(<\mathrm{DD}_{2}\right)$ and determinate type $\left(<\mathrm{DDh}_{2}\right)$ mungbean varieties. Lower estimates of degree of 
TABLE 4 | Estimates of gene effects with standard error and $\chi^{2}$ values of the fitted models for plant height and related traits in mungbean.

\begin{tabular}{|c|c|c|c|c|c|c|c|c|}
\hline Traits & Cross combination & m ( \pm SE) & [d] $( \pm S E)$ & [h] ( \pm SE) & [i] $( \pm S E)$ & [j] ( $( \pm$ SE) & [I] (土SE) & $\chi^{2}$ (d.f) \\
\hline \multirow[t]{2}{*}{ Plant height at first flower initiation } & AZRI-2006 × 97006 & $84.5 \pm 0.8$ & $6.15 \pm 0.3$ & $-2.80 \pm 0.5$ & & & & $1.60(3)$ \\
\hline & NM-2006 × AUM-9 & $24.8 \pm 0.2$ & $4.21 \pm 0.2$ & $-3.39 \pm 0.5$ & & & & $0.01(3)$ \\
\hline \multirow[t]{2}{*}{ Plant height at first pod maturity } & AZRI-2006 ×97006 & $38.1 \pm 1.2$ & $19.7 \pm 0.4$ & $-8.92 \pm 1.7$ & $-8.79 \pm 1.29$ & $-13.3 \pm 1.0$ & & $3.80(1)$ \\
\hline & NM-2006 × AUM-9 & $35.3 \pm 0.4$ & $5.91 \pm 0.4$ & & $3.33 \pm 0.56$ & & & $0.10(3)$ \\
\hline \multirow[t]{2}{*}{ Plant height at $90 \%$ pods maturity } & AZRI-2006 × 97006 & $59.6 \pm 1.3$ & $45.6 \pm 0.3$ & $-19.2 \pm 1.6$ & $-17.4 \pm 1.33$ & $-22.9 \pm 1.2$ & & $0.80(1)$ \\
\hline & NM-2006 × AUM-9 & $59.9 \pm 1.6$ & $9.80 \pm 0.5$ & $-11.9 \pm 2.0$ & $-7.36 \pm 1.70$ & & & $0.10(2)$ \\
\hline \multirow[t]{2}{*}{$\mathrm{DDh}_{1}$} & AZRI-2006 × 97006 & $45.4 \pm 0.7$ & $10.8 \pm 0.7$ & $8.79 \pm 3.6$ & & $-7.30 \pm 1.8$ & $-8.85 \pm 3.6$ & $0.20(1)$ \\
\hline & NM-2006 × AUM-9 & $37.5 \pm 0.4$ & $2.32 \pm 0.3$ & $-17.9 \pm 1.7$ & & $6.10 \pm 0.9$ & $21.4 \pm 1.7$ & $1.10(1)$ \\
\hline \multirow[t]{2}{*}{$\mathrm{DDh}_{2}$} & AZRI-2006 × 97006 & $53.9 \pm 0.6$ & $8.04 \pm 0.6$ & $31.5 \pm 2.9$ & & $-12.8 \pm 1.6$ & $-31.8 \pm 2.9$ & $0.30(1)$ \\
\hline & NM-2006 × AUM-9 & $47.2 \pm 1.2$ & $0.96 \pm 0.4$ & $11.5 \pm 1.5$ & $6.84 \pm 1.27$ & $9.50 \pm 1.1$ & & $3.00(1)$ \\
\hline \multirow[t]{2}{*}{$\mathrm{DDh}_{3}$} & AZRI-2006 × 97006 & $32.2 \pm 0.6$ & $4.12 \pm 0.6$ & $16.9 \pm 2.9$ & & $-4.90 \pm 1.5$ & $-17.6 \pm 2.9$ & $0.10(1)$ \\
\hline & NM-2006 × AUM-9 & $27.3 \pm 0.3$ & $2.27 \pm 0.3$ & $4.08 \pm 0.6$ & & & & 0.01 (3) \\
\hline \multirow[t]{2}{*}{ Nodes per plant } & AZRI-2006 × 97006 & $7.68 \pm 0.4$ & $2.06 \pm 0.1$ & $3.65 \pm 0.5$ & & & $-0.74 \pm 0.1$ & $0.05(2)$ \\
\hline & NM-2006 × AUM-9 & $6.48 \pm 0.3$ & $2.56 \pm 0.4$ & $5.50 \pm 0.9$ & & & $-1.97 \pm 0.1$ & $0.04(2)$ \\
\hline \multirow[t]{2}{*}{ Biological yield per plant } & AZRI-2006 × 97006 & $61.5 \pm 1.1$ & $13.7 \pm 0.7$ & $9.25 \pm 0.5$ & & $-10.5 \pm 1.1$ & $-5.84 \pm 0.4$ & $2.51(2)$ \\
\hline & NM-2006 × AUM-9 & $58.8 \pm 1.8$ & $7.58 \pm 0.5$ & & $5.58 \pm 0.21$ & $-8.99 \pm 1.2$ & & $1.23(2)$ \\
\hline \multirow[t]{2}{*}{ Harvest index (\%) } & AZRI-2006 × 97006 & $21.6 \pm 0.5$ & $3.56 \pm 0.2$ & $11.6 \pm 1.4$ & & $4.15 \pm 0.4$ & & $0.30(2)$ \\
\hline & NM-2006 × AUM-9 & $23.5 \pm 0.4$ & $6.14 \pm 0.9$ & & & $-4.84 \pm 0.4$ & & $2.41(3)$ \\
\hline \multirow[t]{2}{*}{ Seed yield per plant } & AZRI-2006 × 97006 & $13.2 \pm 0.2$ & $0.31 \pm 0.1$ & $1.60 \pm 0.3$ & $0.56 \pm 0.20$ & & & $0.70(2)$ \\
\hline & NM-2006 × AUM-9 & $13.8 \pm 0.1$ & $1.20 \pm 0.1$ & $-0.96 \pm 0.1$ & & & & $0.06(3)$ \\
\hline
\end{tabular}

m, mean; [d], additive; [h], dominance; [i], additive $\times$ additive; [j], additive $\times$ dominance; [l], dominance $\times$ dominance.

indeterminations in the approved varieties could serve as an eye opener for the breeders, regarding the possibility of reduction/elimination of the phenomenon of indeterminate growth habit in mungbean through genetic means. The same feature of the said varieties could be manipulated in the future breeding programmes. The accession 97006 and AUM- 9 by virtue of their asynchronous and twinning growth habit could serve as potential parent for crop growth related studies.

The significance of only D and E component in genetic variance analysis exhibited the pre-pondrance of additive and environmental components. The environment could fluctuate the plant height and its degree of indeterminations but with nominal impact. Genotypic $\times$ environmental interaction and its involvement in the inheritance were also reported by Deswal et al. (1996) in wheat and Khattak et al. (2002a) in mungbean. Additive genetic variance played a vital role in the inheritance of investigated traits, might be due to high narrow sense heritability $\left(\mathrm{h}_{\mathrm{F} 2}^{2}\right.$ and $\left.\mathrm{h}_{\mathrm{F} \alpha}^{2}\right)$ estimates. The same reiterated the involvement of few major genes and similar genetic effects and likelihood of genetic improvement of all the studied traits. Any protective measure that could minimize the experimental error may improve the estimate of heritability of a trait (Fehr, 1987). Khattak et al. (2002b) also computed high narrow and broad sense heritability estimates for $\mathrm{DDh}_{2}$, They further explained that better response to selection is possible for the development of mungbean genotypes with minimum increase in plant height during post-flowering development. Engagements of epistasis for most of the traits in the present study reaffirm the availability of sufficient genetic variation. A negative dominance for plant height approaching reproductive phase and seed yield per plant specified the involvement of sufficient negative genes. Due to the accumulation of negative genes selection for dwarf type plants at blooming phase with higher seed yield could be postponed to later generation until the accretion of favorable genes. However, the dominance in case of $\mathrm{DDh}_{3}$ is toward lower degree of indetermination, therefore for the same selection could be practice in early segregating generation. So bulk, pedigree or single seed descendent method of selection could be opted. Presence of higher magnitude of additive gene action for plant height was reported by Sharma et al. (2008) in peas and Verma et al. (2007) in barley. Additive and dominance gene action governed the inheritance of most traits in long bean (Rahman and Saad, 2000) and for plant height at first and $90 \%$ pods maturity, $\mathrm{DDh}_{1}, \mathrm{DDh}_{2}$, and $\mathrm{DDh}_{3}$ in mungbean (Khattak et al., 2002b). Duplicate epistasis was observed for the inheritance of plant height in mungbean (Ajmal et al., 2007; Khodambashi et al., 2012). Involvement of non-additive gene action for the inheritance of seed yield was reported by Kunkaew et al. (2007) in adzuki bean and Sujatha and Kajjidoni (2013) in greengram 
TABLE 5 | Best fit model following weighted analysis of components of variation and narrow sense heritability estimates in two crosses of mungbean.

\begin{tabular}{|c|c|c|c|c|c|c|}
\hline Traits & Cross combination & \multicolumn{2}{|c|}{ Variance components } & $x^{2}(4 \mathrm{df})$ & \multicolumn{2}{|c|}{ Heritability (\%age) } \\
\hline & NM-2006 $\times$ AUM-9 & $36.07 \pm 4.49$ & $4.336 \pm 0.63$ & 1.123 & 80.6 & 90.3 \\
\hline Plant height at first pod maturity & AZRI-2006 × 97006 & $65.19 \pm 9.02$ & $10.36 \pm 1.52$ & 1.680 & 75.8 & 86.3 \\
\hline \multirow[t]{2}{*}{ Plant height at 90\% pods maturity } & AZRI-2006 × 97006 & $119.6 \pm 12.1$ & $6.433 \pm 0.95$ & 1.317 & 90.3 & 94.9 \\
\hline & NM-2006 × AUM-9 & $127.6 \pm 19.1$ & $14.03 \pm 2.07$ & 1.428 & 86.0 & 92.5 \\
\hline \multirow[t]{2}{*}{$\mathrm{DDh}_{1}$} & AZRI-2006 × 97006 & $206.1 \pm 28.2$ & $31.90 \pm 4.68$ & 2.461 & 76.4 & 86.6 \\
\hline & NM-2006 × AUM-9 & $44.62 \pm 6.58$ & $8.176 \pm 1.19$ & 1.920 & 73.2 & 84.5 \\
\hline $\mathrm{DDh}_{3}$ & NM-2006 × AUM-9 & $39.96 \pm 5.63$ & $6.614 \pm 0.97$ & 0.509 & 75.1 & 85.8 \\
\hline \multirow[t]{2}{*}{ Node per plant } & AZRI-2006 × 97006 & $18.12 \pm 2.93$ & $6.251 \pm 0.87$ & 0.957 & 78.0 & 82.1 \\
\hline & NM-2006 × AUM-9 & $6.547 \pm 0.35$ & $0.420 \pm 0.85$ & 1.351 & 71.2 & 82.4 \\
\hline \multirow[t]{2}{*}{ Biological yield per plant } & AZRI-2006 × 97006 & $202.5 \pm 24.1$ & $36.1 \pm 3.58$ & 3.042 & 69.7 & 82.6 \\
\hline & NM-2006 × AUM-9 & $31.92 \pm 4.14$ & $5.16 \pm 0.91$ & 1.122 & 68.2 & 64.9 \\
\hline \multirow[t]{2}{*}{ Harvest index (\%) } & AZRI-2006 × 97006 & $26.98 \pm 3.19$ & $2.452 \pm 0.35$ & 0.645 & 70.4 & 83.1 \\
\hline & NM-2006 $\times$ AUM-9 & $33.85 \pm 4.84$ & $3.150 \pm 0.84$ & 1.452 & 73.4 & 83.4 \\
\hline Seed yield per plant & AZRI-2006 × 97006 & $3.262 \pm 0.32$ & $0.137 \pm 0.021$ & 0.251 & 92.6 & 96.0 \\
\hline
\end{tabular}

$D$, additive variance; $E$, environmental variance; $h^{2}(F 2)$, narrow sense heritability $F 2$ generation and $h^{2}(F \propto)$, narrow sense heritability $F$ infinite generation.

and additive, dominance and non-allelic interactions for plant height have also been document in greengram (Singh et al., 2007). Various negative digenic epistatic interactions witnessed in the present study reflect the non-availability of favorable genes. Non-additive gene action for seed yield in cowpea was also observed (Dijee et al., 2000). The inheritance of plant height is governed by non-additive gene action in mungbean (Tiwari et al., 1993) in sweet sorghum (Sankarapandian et al., 1994) and also by duplicate epistasis (Khodambashi et al., 2012) in greengram. Evidence of di-genic non-allelic interactions accompanied with additive and dominance components have also been documented for the inheritance of plant height and degree of indetermination in green gram (Ram, 1997). Additive and non-additive gene actions control the inheritance of plant height in mungbean (Singh et al., 2007) and harvest index in wheat (Chand and Dawa, 1996). Several geneticists witnessed the existence of epistasis in the inheritance of quantitative character in different crops (Pensuk et al., 2004; Bnejd and El- Gazzah, 2008, 2010; Shashikumar et al., 2010). Accumulation and clustering of interacting sets of genes with additive influence could provide a path for the genetic improvement of quantitative traits. Digenic epistatic interactions governed the inheritance of most of the studied traits. For the exploitation of such epistasis, development of multiple crosses and rising of large segregating populations followed be inter se mating of desired segregants could help in piling-up the frequency of additive genes. Intermating or recurrent selection would be followed for genetic enhancement of grain yield in mungbean (Payasi et al., 2010). The same will also favor the development of potential transgressive segregants and breakage of unwanted linkages. After inter mating the desired segregants, one or two cycles of recurrent selection and each cycle of selection followed by selfing to one generation while deferring the final selection to later filial generation could serve as a good promising method for the elimination of negative genes and development of dwarf and determinate type mungbean lines with high harvest index. Singh and Pawar (1990) also suggested recurrent selection procedures for the exploitation of non-additive genetic variability.

\section{Conclusion}

The choice of most suitable parents, careful planning of crosses, selection and intermating of desired segregants could be the key factors for devising a work oriented breeding programme for restricting the indeterminate growth in mungbean. 


\section{References}

Ajmal, S. U. Zubair, M., and Anwar, M. (2007). Genetic implication of yield and its components in mungbean Vigna radiata (L.) Wilczek. Pak. J. Bot. 39, 1229-1236.

Ali, M. A., Khan, I. A., Awan, S. I., Ali, S., and Niaz, S. (2008). Genetics of fibre quality traits in cotton (Gossypium hirsutum L.). Aus. J. Crop Sci. 2, 10-17.

Benlloch, R., Berbel, A., Settano-Mislata, A., and Madueño, F. (2007). Floral initiation and inflorescence architecture: a comparative view. Ann. Bot. 100, 659-676. doi: 10.1093/aob/mcm146

Bnejd, F., and El- Gazzah, M. (2008). Inheritance of resistance to yellow berry in durum wheat. Euphytica 163, 225-230. doi: 10.1007/s10681-007-9632-y

Bnejd, F., and El- Gazzah, M. (2010). Epistasis and genotype-by-environment interaction of grain yield related traits in durum wheat. J. Plant Breed. Crop Sci. 2, 24-29. doi: 10.5897/JPBCS

Chand, K., and Dawa, T. (1996). Inheritance of physiological and phenological traits in bread wheat. J. Hill Res. 9, 317-320.

Deswal, R. K., Grakh, S. S., and Berwal, K. K. (1996). Genetic variability and characters association between grain yield and its components in wheat. Ann. Biol. 12, 221-224.

Dijee, B., Kandasamy, G., Sakila, M., Shunmugavalli, N., and Bastian, D. (2000). Combining ability for yield and components in cowpea. Res. Crops 1, 239-244.

Fehr, W. R. (1987). "Heritability," in Principles of Cultivar Development: Theory and Techniques, Vol. 1, ed W. P. Fehr (New York, NY: Macmillan Pub. Co.), 95-105.

Huyghe, C. (1998). Genetics and genetic modifications of plant architecture in grain legumes: a review. Agronomie 18, 383-411. doi: 10.1051/agro:19980505

Khattak, G. S. S., Ashraf, M., Haq, M. A., McNeilly, T., and Rha, E. S. (2002b). Genetic basis of plant height and its degree of indetermination in mungbean (Vigna radiata (L.) Wilczek). Hereditas 137, 52-56. doi: 10.1034/j.16015223.2002.1370107.x

Khattak, G. S. S., Ashraf, M., and Zamir, R. (2004). Gene action for synchrony in pod maturity and indeterminate growth habit in mungbean (Vigna radiata (L.) Wilczek). Pak. J. Bot. 36, 589-594.

Khattak, G. S. S., Haq, M. A., Ashraf, M., Jabbar, A., and Zamir, R. (2002a). Genetic architecture of secondary yield components in mungbean (Vigna radiata (L.) Wilczek). Breed Sci. 52, 235-241. doi: 10.1270/jsbbs.52.235

Khodambashi, M. M., Bitaraf, N., and and Hoshmand, S. (2012). Generation mean analysis for grain yield and its related traits in lentil. J. Agric. Sci. Tech. 14, 609-616.

Kilgore-Norquest, L., and Sneller, C. H. (2000). Effect of stem termination on soybean traits in southern U.S. production systems. Crop Sci. 40, 83-90. doi: $10.2135 /$ cropsci2000.40183x

Kunkaew, W., Julsrigival, S., Senthong, C. H., and Karladee, D. (2007). Inheritance of seed yield in adzukibean (Vigna angularis Willd). C.M.U. J. Nat. Sci. 6, 341.

Kwaye, G. R., Shimelis, H., and William, P. M. (2008). Combining ability analysis and association of yield and yield components among selected cowpea lines. Euphytica 162, 205-210. doi: 10.1007/s10681-007-9512-5

Lampang, A. N., Pichitporn, S., Sin, S. S., and Vanakijinongkol, N. (1988). "Mungbean growth pattern in relation to yield," in Mungbean Proceedings of 2nd International Symposium AVRDC, ed S. Shaninugasundaram (Tainan, Taiwan,), 164-168.

Little, T. M., and Hills, F. J. (1978). Agricultural Experimentations-Design and Analysis. New York, NY: Wiley.

Manifesto, M. M., Schlatter, A. R., Hopp, H. E., Suarez, E. Y., and Dubcovsky, J. (2001). Quantitative evaluation of genetic diversity in wheat germplasm using molecular markers. Crop Sci. 41, 682-690. doi: 10.2135/cropsci2001.413682x

Mather, K., and Jinks, J. L. (1982). Biometrical Genetics, 3rd Edn. London: Chapman and Hall. doi: 10.1007/978-1-4899-3406-2

Ouattara, S., and Weaver, D. B. (1994). Effect of growth habit on yield and agronomic characteristics of late-planted soybean. Crop Sci. 34, 870-873 doi: 10.2135/cropsci1994.0011183X003400040008x

Payasi, D., Pandey, S., Nair, S. K., and Pandey, R. L. (2010). Generation mean analysis for yield and yield components in mungbean (Vigna radiata L.Wilczek). Int. J. Plant Sci. 5, 485-493.

Pensuk, V., Jogloy, S., Wongkaew, S., and Patanothai, A. (2004). Generation means analysis of resistance to peanut bud necrosis caused by peanut bud necrosis tospovirus in peanut. Plant Breed. 123, 90-92. doi: 10.1046/j.01799541.2003.00928.x

Podleœny, J. (2001). The effect of drought on the development and yielding of two different varieties of the fodder broad bean (Vicia faba minor). J. Appl. Gen. 42, 283-287.

Rahman, M. A., and Saad, M. S. (2000). Estimation of additive, dominance and digenic epistatic interaction effects for certain yield characters in Vigna sesquipedalis Fruw. Euphytica 114, 61-66. doi: 10.1023/A:10039856 10940

Ram, T. (1997). Gene action for certain quantitative characters in green gram (Vigna radiata (L.) Wilczek). Indian. J. Genet. 57, 143-148.

Reddy, S. R. (2004). Principles of Crop Production, 2nd Edn. New Delhi: Kalyani Publishers.

Rehman, A., Ali, M. A., Ali, B. M., Saleem, M., Abbas, A., and Mallahi, A. R. (2009). Genetic studies of yield related traits in mungbean (Vigna radiata L. Wilczek). Aust. J. Crop Sci. 3, 352-360.

Rehman, A., Ali, M. A., Saleem, M., and Tadesse, W. (2010). Study of heritable variation and genetics of earliness in mungbean (Vigna radiata (L.) Wilczek). Euphytica 176, 331-339. doi: 10.1007/s10681-010-0208-x

Robinson, S. L., and Wilcox, J. R. (1998). Comparison of determinate and indeterminate soybean near-isolines and their response to row spacing and planting date. Crop Sci. 38, 1554-1557. doi: 10.2135/cropsci1998.0011183X003800060024x

Sankarapandian, R., Ramalingam, J., Pillai, M. A., and Vanniarajan, C. (1994). Heterosis and combining ability studies for juice yield related characteristics in sweet sorghum. Ann. Agric. Res. 15, 199-204.

Shanmugasundaram, S., Tsou, C. S., and Samson, S. T. T. (1977). Selection of plant types in breeding tropical soybean. Bull. Inst. Trop. Agr. Kyushu Univ. 2, 25-39.

Sharma, A., Singh, G., Singh, Y., and Sood, S. (2008). Detection of genetic components of variation for biometrical traits in garden pea. Int. J. Veg. Sci. 14, 67-80. doi: 10.1080/19315260801890658

Shashikumar, K. T., Pitchaimuthu, M., and Rawal, R. D. (2010). Generation mean analysis of resistance to downy mildew in adult muskmelon plants. Euphytica 173, 121-127. doi: 10.1007/s10681-010-0132-0

Singh, S., and Pawar, I. S. (1990). An appraisal of selection methods in self fertilized crops. Trends Crop Improv. 44, 17-26.

Singh, V. K., Tyagi, K., Tomer, A. K., Singh, M. N., and Nandan, R. (2007). Gene action for yield and yield atiributing traits in mungbean (Vigna radiata (L.) Wilczek). Legume Res. 30, 29-32.

Steel, R. G. D., Torrie, J. H., and Deekey, D. A. (1997). Principles and Procedures of Statistics: A Biometrical Approach, 3rd Edn. New York, NY: McGraw Hill Book Co.

Sujatha, K., and Kajjidoni, S. T. (2013). Genetic analysis involving selected powdery mildew resistant lines in mungbean (Vigna radiata (L.) Wilczek). Mol. Plant Breed. 4, 38-43.

Tickoo, J. L., Gajraj, M. R., and Manji, C. (1996). "Plant type in mungbean (Vigna radiata (L.) wilczek)," in Proc. Recent Adv. in Mungbean Res, eds A. N. Asthana and D. H. Kim (Kanpur: Indian Soc. of Pulses Res), 197-213.

Tiwari, D. S., Singh, V., and Shukla, P. S. (1993). Combining ability studies in mungbean (Vigna radiata (L) Wilczek). Indian J. Genet. 53, 395-398.

Verma, A. K., Vishwakarma, S. R., and Singh, P. K. (2007). Genetic architecture for yield and quality component traits over two environments in barley (Hordeum vulgare L.). Barley Genet. Newsl. 37, 24-38.

Weberling, F. (1989). Morphology of Flowers and Inflorescences. Cambridge: Cambridge University Press.

Conflict of Interest Statement: The authors declare that the research was conducted in the absence of any commercial or financial relationships that could be construed as a potential conflict of interest.

Copyright (c) 2015 Iqbal, Ahsan, Saleem and Ali. This is an open-access article distributed under the terms of the Creative Commons Attribution License (CC BY). The use, distribution or reproduction in other forums is permitted, provided the original author(s) or licensor are credited and that the original publication in this journal is cited, in accordance with accepted academic practice. No use, distribution or reproduction is permitted which does not comply with these terms. 